\title{
EFFECTS OF OXIDISED OILS ON INFLAMMATION-RELATED CANCER RISK
}

\section{TAN PEI YEE* and TENG KIM TIU^}

\begin{abstract}
The practice of using cooking oils that are heated repeatedly is common to reduce the expenses of food preparation. However, this will result in lipid peroxidation, which generates compounds that are toxic to human health. Prolonged consumption of oxidised oils may affect lipid metabolism, which generates free radicals and products that will lead to pro-inflammatory pathways. A number of cellular, animal and clinical studies have revealed the effects of oxidised oils on inflammatory responses. By-products of lipid peroxidation, including trans, trans-2,4-decadienal (2.4-De), 4-hydroxy-2-hexenals (4-HHE) and malonaldehyde (MDA) can be found significantly in samples treated with oxidised oils. Besides, the release of inflammatory biomarkers or cytokines will be induced due to the enhanced degree of oxidative stress. Inflammation has been acknowledged to be linked to increased risk of cancer. Therefore, the consumption of repeatedly heated oils, which have higher level of oxidation may potentially lead to cancer progression. The possible cancer risk induced by the dietary intake of pro-inflammatory oxidised oils, methodology considerations and limitations of studies related to cancer risk induced by pro-inflammatory oxidised oils will be discussed in this review.
\end{abstract}

Keywords: oxidised oils, lipid peroxidation, oxidative stress, inflammation, cancer.

Date received: 28 June 2018; Sent for revision: 2 July 2018; Received in final form: 14 January 2019; Accepted: 16 January 2019.

\section{INTRODUCTION}

Deep frying is one of the most regularly used cooking methods worldwide. The consumption of deep-fried food is prevalent, particularly in developing countries. Highly oxidised lipids are consumed via dietary intake of these deep-fried foods. As large amount of edible vegetable oils are required during deep frying process, they are usually used repeatedly to ensure cost effectiveness (Leong et al., 2015).

Frying oils heated at high temperature will lead to lipid peroxidation, followed by generation of toxic compounds such as trans-2,4-decadienal

\footnotetext{
Malaysian Palm Oil Board

6 Persiaran Institusi, Bandar Baru Bangi,

43000, Kajang, Selangor, Malaysia.

E-mail: kimtiu@mpob.gov.my
}

(2,4-De), 4-hydroxy-2-hexenals (4-HHE) and Malonadehyde (MDA) (Chang et al., 2005; Boyd and McGuire, 1991). The range of frying temperature is advised to be between $160^{\circ} \mathrm{C}$ and $180^{\circ} \mathrm{C}$ as oils deteriorate more rapidly at higher temperatures while frying products absorb more oils at lower temperatures (Freire et al., 2013). Repeatedly heating the oils will increase the degree of lipid peroxidation and thus exert adverse effects on health (Jaarin and Kamisah, 2012). Previous studies have reported that the consumption of oxidised oils will increase the risk of inflammation-induced diseases such as atherosclerosis, high blood pressure, gastric ulceration and cancers (Leong et al., 2008; Obembe et al., 2016). Furthermore, free radicals produced during lipid peroxidation may lead to oxidative stress, subsequently activate a number of molecular pathways that generate inflammatory molecules, such as interleukin 1 beta (IL-1 $\beta$ ), interleukin 6 
(IL-6) and tumour necrosis factor alpha (TNF- $\alpha$ ) (Patterson et al., 2012). The production of these inflammatory molecules has been reported to have tumour-promoting effects, which is also associated to increased risk of cancers.

In this review, the mechanism and products of lipid peroxidation will be discussed. Besides, the inflammatory effects of oxidised oils will be reviewed based on previous research. The potential risk of cancers induced by inflammation due to intake of oxidised oils will also be discussed.

\section{LIPID PEROXIDATION}

Lipid peroxidation can be defined as the oxidative deterioration of lipids in which the oxidants, such as free radicals or non-radical species attack the carbon-carbon double bonds of lipids (Ayala et al., 2014). This process encompasses the removal of hydrogen from a carbon, with the addition of oxygen molecule, producing lipid peroxyl radicals and hydroperoxides, which are the primary oxidation products (Choe and Min, 2006). The lipid oxidation process in oils can be increased by several intrinsic factors, for example, presence of pro-oxidants and antioxidants, fatty acid composition and water content, as well as external factors such as increased temperature, oxygen and light.

Rate of lipid oxidation is increased with the degree of unsaturation of the oil (Kris-Etherton and Committee, 1999). Due to the presence of double bonds, polyunsaturated fatty acids (PUFA) are more prone to oxidation compared to saturated fatty acids (SFA). The rate of oxidation of SFA was reported to decrease with increasing chain length (laurate $>$ palmitate $>$ stearate). In contrary, the rate of oxidation of unsaturated fatty acids was found to increase in the following order: linolenate $>$ oleate $>$ linoleate (Leyton et al., 1987; DeLany et al., 2000).

The primary oxidation products, such as: lipid hydroperoxides, are usually stable at moderate conditions, such as room temperature and without the presence of metals. However, the existence of metals or high temperature condition will cause them to be easily decomposed to alkoxy radicals and then generate secondary oxidation products
(Choe and Min, 2006). Lipid peroxides and some of their bi-functional products may interact with the biological components, including enzymes, membranes and proteins, affecting vital cell functions (Frankel, 1984; Pizzimenti et al., 2013). The decomposition of hydroperoxides usually takes place by the breaking of oxygen-oxygen bond (Pizzimenti et al., 2013), producing alkoxy and hydroxyl radicals. Subsequently, the alkoxy radical will go through the process of homolytic $\beta$-scission of carbon-carbon bond, which results in the production of oxo-compounds and saturated or unsaturated alkyl radicals. It is followed by electron arrangement, addition of hydroxyl radical or transfer of hydrogen, generating the secondary lipid oxidation products (Choe and Min, 2006).

Secondary oxidation products are usually low molecular-weight molecules, such as aldehydes, alcohols, ketones and short-chain hydrocarbons (Choe and Min, 2006). Some of the secondary products are still unstable and will be further degraded to generate tertiary oxidation products, such as short chain free fatty acids (Lise Halvorsen and Blomhoff, 2011). The types of primary, secondary and tertiary lipid oxidation products are listed in Table 1.

The 4-Hydroxynomenal (4-HNE), as one of the examples of secondary oxidation product, is generated from the cleavage of omega- 3 or omega- 6 PUFA (Bremner et al., 1997). Elevated amount of 4-HNE can be observed in plasma and many organs that undergo oxidative stress (Esterbauer and Cheeseman, 1990). Besides, MDA as one of the secondary products of lipid peroxidation in the cells, is generally used to determine the oxidative stress and antioxidant status of cancerous patients (Gaweł et al., 2003).

\section{BIOCHEMICAL INDICES}

The oxidation level of oil samples can be assessed by performing biochemical tests. The biochemical indices that are generally used to determine the oxidation level of oils include peroxide value (PV), free fatty acid (FFA) value and $p$-anisidine value $(p$ $\mathrm{AV})$, which will be discussed in this section.

TABLE 1. PRIMARY, SECONDARY AND TERTIARY PRODUCTS OF LIPID OXIDATION

\begin{tabular}{lll}
\hline Primary oxidation products & \multicolumn{1}{c}{ Secondary oxidation products } & Tertiary oxidation products \\
\hline & Aldehydes; alcohols; ketones; hydrocarbons; & esters; furans; lactones; epoxides; cyclic and \\
Lipid hydroperoxides & hydroxyl deriatives of lipid hydroperoxides; & Short chain free fatty acids \\
& monocyclic, biclyclic, aliphatic, dimeric and & \\
& trimeric products of polymerisation or \\
& copolymerisation \\
\hline
\end{tabular}

Source: Adopted from Dabrowska et al. (2015). 


\section{Peroxide Value}

PV measures the concentration of peroxides formed during the primary stages of oxidation. It is generally used to determine the degree of rancidity of oils due to auto- and photo-oxidation, therefore it is useful to assess the extent to which spoilage has taken place (Kaleem et al., 2015). In addition, it is widely used in quality control of oils. Oils with higher level of unsaturation are more prone to auto-oxidation (Mannekote and Kailas, 2012; Kaleem et al., 2015). For instance, oleic acid (C18:1) which has higher degree of unsaturation compared to linoleic acid (C18:2) has been estimated to have lower susceptibility to oxidation (Yun and Surh, 2012).

The PV of oil samples can be altered by the condition of storage. Oil samples may be influenced by light, which induces photooxidation (Abdelmonem and Khogali, 2012). According to Anwar et al. (2007), PV of soyabean oil samples stored under sunlight increased significantly compared to those stored at ambient. Furthermore, the conditions and climate of the area where refinement process takes place have been reported to affect the oxidation level of oils, resulting in differences in PV (Kaleem et al., 2015). In addition to that, longer storage time has also been found to increase the degree of oxidation of oil samples (Zahir et al., 2017).

Besides, higher PV can be obtained in the oil samples reheated more frequently. Therefore, higher PV denotes reduced chemical stability of the oil samples (Leong et al., 2015). During heating of oil samples, the trend of PV may be unstable as the hydroperoxides formed are very unstable and easily break down into various types of volatile and non-volatile products. Therefore, an increased level of PV of oil samples may appear at the beginning of heating process due to the high concentration of hydroperoxides formed, followed by a decreased PV level when secondary oxidation products are detected (Kaleem et al., 2015). However, PV is not able to quantify the actual oxidative degradation as further breakdown of peroxides usually occurs, therefore simultaneous measurement of secondary products would be appropriate (Barriuso et al., 2013).

\section{Free Fatty Acid Value}

FFA are the products of the hydrolysis of oils and fats (Mahesar et al., 2014). Throughout the heating process, the moisture present in the oil samples will induce hydrolysis reaction, which involves the breakage of triglycerides, producing glycerol, di- and mono-acylglycerols, and FFA (Nayak et al., 2016). Hydrolysis occurs more easily in oil containing short and unsaturated fatty acids compared to oil containing long and saturated fatty acids as the water solubility of short and unsaturated fatty acids are higher than long and saturated fatty acids (Choe and Min, 2007).

FFA are also known as pro-oxidants and the effects are subjected to the type of fatty acids (Waraho et al., 2011). The pro-oxidant action of FFA might be due to the presence of carboxylic groups which increase the rate of breakdown of hydroperoxides (Miyashita and Takagi, 1986; Fregaa et al., 1999). FFA determination is relatively rapid and reliable, therefore it is one of the widely used quality indices during food processing, manufacturing, storage and marketing of edible oils (Ali and Abdurrhman, 2013; Ahmad Tarmizi and Ismail, 2007). FFA content is one of the widely used quality indices during manufacturing, storage and marketing of edible oils (Ali and Abdurrhman, 2013). Acid value is used to measure the concentration of FFA in oil. Higher acid value is recorded in oil samples with higher level of FFA, which indicates decreased oil quality (Atinafu and Bedemo, 2011).

\section{$p$-Anisidine Value}

During lipid oxidation, hydroperoxides, the primary oxidation products, breakdown to generate secondary oxidation products (alcohols, aliphatic aldehydes, acids, hydrocarbons and ketones) which have higher stability during the heating process, in control of the off-flavours and off-odours of edible oils. Simultaneous detection of primary and secondary lipid oxidation products is essential to ensure a better monitoring of lipid oxidation process during the heating process. It has been reported that $p$-AV is a reliable measurement of the level of secondary oxidation products (Poiana, 2012). The $p$-AV test evaluates the concentration of aldehydes, predominantly 2-alkenals, exist in the oil. The $p$-AV increased in the soyabean oil samples with the longer of storage time under light, indicating an increase in oxidation level. The reaction between aldehydic compounds in oil samples and $p$-anisidine will lead to an increase in absorbance at $350 \mathrm{~nm}$. The pattern of variations in $p$-AV of the oil samples was comparable to the variations in their $p$-AV (Yildiz et al., 2001).

The generation of secondary oxidation products varies with different types of oil (Kaleem et al., 2015). A study reported that $p$-AV increased more significantly in oil samples undergoing deep-frying process, followed by air-light exposure, and air exposure. Besides, $p$-AV of oil samples increased in the following order: soyabean $>$ corn $>$ olive (Naz et al., 2004). The $p$-AV values also increased due to prolonged storage. According to Mohdaly et al. (2010), the $p$-AV of the oil samples reached a maximum value after $72 \mathrm{hr}$ of storage (Mohdaly et al., 2010). 


\section{MECHANISMS UNDERLYING LIPID OXIDATION-INDUCED INFLAMMATION}

The consumption of oxidised oils may affect the lipid metabolism, which can be detected by the changes in tissue fatty acid composition (Kummerow et al., 2004). Based on a previous study, increased amounts of arachidonic acid (AA) in tissue lipids were detected in animals fed on oxidised oil (Eder, 1999). AA can be converted to eicosanoids that play a significant role in inflammatory processes, such as prostaglandins, thromboxanes, and leukotrienes by cyclooxygenases (COX) and lipoxygenases (LOX) (Patterson et al., 2012; Calder, 2009). Leukotriene $\mathrm{B}_{4}\left(\mathrm{LTB}_{4}\right)$ has many pro-inflammatory roles, such as acting as chemotactic agent for leukocytes, activating neutrophils, accelerating generation of reactive oxygen species (ROS), inducing discharge of lysosomal enzymes, and increasing vascular permeability. The $\mathrm{LTB}_{4}$ also increases generation of inflammatory cytokines, such as IL-1 $\beta$, IL-6 and TNF- $\alpha$ by macrophages. The excess production of prostaglandin has a number of pro-inflammatory effects. For instance, prostacyclin $\left(\mathrm{PGI}_{2}\right)$ and prostaglandin E2 $\left(\mathrm{PGE}_{2}\right)$ play a significant role in the development of arthritis by mediating acute inflammatory response. In addition, $\mathrm{PGE}_{2}$ can increase its own synthesis via induction of COX-2, followed by increased production of IL- 6 , a proinflammatory cytokine in macrophages (Patterson et al., 2012).

The oxidation of lipids will lead to production of dietary lipid oxidation end products in a substantial amount, which are cytotoxic and genotoxic. Besides, the free radicals generated throughout lipid oxidation may lead to oxidative stress, which activate the nuclear factor $\mathrm{kB}(\mathrm{NFKB})$ (Maehre et al., 2015). The NF-kB regulates a number of cytokines (e.g., IL-1, IL-2, IL-6, IL-12, and TNF- $\alpha$ ), chemokines (e.g., IL-8, monocyte chemoattractant protein-1), cell adhesion molecules (e.g., sICAM, sVCAM), and inducible effector enzymes (e.g., inducible nitric oxide synthase and COX-2) (Patterson et al., 2012). After the dietary intake of oxidised lipids, several dietary lipid oxidation end products, which are absorbed from the intestine to the circulatory system, may function as injurious chemicals that induce inflammatory response which exert impacts not only to circulatory system but also organs, such as the liver, lung, kidney and the gut itself (Kanner, 2007). The consumption of oxidised lipids will destroy essential fatty acids in body, generating toxic compounds and oxidised polymers (Sadoudi et al., 2013). Dietary oxidised fats may enhance LDL cholesterol modification via their lipid peroxidation products (Eder et al., 2003). For instance, oxidised fatty acids can be absorbed into the intestine, followed by esterification to form complex lipids and integration into lipoproteins (Penumetcha et al., 2000).
Dietary oxidised fats have been found to increase the susceptibility of lipoprotein to oxidation (Silaste et al., 2004).

Oxidised low-density lipoprotein (LDL) is a potent inducer for the production of inflammatory molecules. Oxidised LDL may stimulate macrophages, which generates intracellular ROS/ reactive nitrogen species (ROS/RNS) by several pathways, such as the nicotinamide adenine dinucleotide phosphate (NADPH) oxidase (NOX) system, the lipoxygenase/cyclooxygenase system, inducible nitric oxide synthase (iNOS), and mitochondrial respiratory chain. Besides, intracellular ROS produced via stimulation of oxidised LDL can induce a number of proinflammatory and pro-apoptotic pathways that are controlled by transcription factors, such as NF$\mathrm{kB}$, followed by production of pro-inflammatory cytokines that cause oxidative stress by increasing the generation of ROS by macrophages, monocytes, and leukocytes (Straliotto et al., 2013; Patterson et al., 2012). Therefore, oxidised lipids can have an effect on signalling mechanisms, cell proliferation, chemotaxis, and cell survival (apoptosis) (Penumetcha et al., 2000). In a nutshell, the consumption of oxidised oils will lead to intake of a number of by-products which activate several molecular pathways, followed by production of inflammatory molecules, which are known to have promoting effects on tumour growth and therefore increase the risk of cancers.

\section{EVIDENCE ON THE INFLAMMATORY EFFECTS OF OXIDISED LIPIDS}

Many studies have been done to examine the effects of oxidised oils on inflammation, which are known to be one of the factors that increase the risk of cancers. In this section, previous studies performed to investigate the inflammatory effects of oxidised oils by using cellular, animal or human models will be discussed.

\section{Cellular or in vitro Studies}

By-products of lipid oxidation are one of the factors that lead to inflammatory responses. The 2,4De is one of the by-products of peroxidation of PUFA during storage or heating. In a study performed by Chang et al. (2005), an enhanced oxidative stress and production of ROS and a decreased reduced glutathione/oxidised glutathione (GSH/GSSG) ratio were exhibited in cultured human bronchial epithelial cells exposed to 2,4-De for 45 days. Consequently, the enhanced oxidative stress resulted in the release of pro-inflammatory cytokines, such as TNF- $\alpha$ and IL-1 $\beta$.

In contrast, although fish oil contains eicosapentaneoic acids (EPA), an omega-3 fatty 
acid, which are highly polyunsaturated and readily go through auto-oxidation, it has been shown to have beneficial effects in chronic inflammatory diseases (Chaudhary et al., 2004). Compared to unoxidised EPA, oxidised EPA is determined to have more inhibitory effects on pro-inflammatory responses in glomerular endothelial cells, including leukocyte-glomerular endothelial cell interactions, cytokine-induced activation of NF-kB in glomerular endothelial and mesangial cells, as well as cytokineinduced glomerular endothelial and mesangial cells expression of MCP-1 and IL- 8 . These results have been further supported by Sethi et al. (2002) who suggested that the anti-inflammatory effects of oxidised omega-3 fatty acids may be attributed to their characteristics in inhibiting the leukocyte adhesion receptor expression and leukocyteendothelial interactions. Furthermore, oxidation products including peroxides and aldehydes generated from the oxidative modification of EPA might also be responsible for the anti-inflammatory effects via suppression of endothelium-phagocyte interactions (Sethi et al., 1996).

\section{Animal or in vivo Studies}

PUFA are greatly susceptible to oxidation, generating potentially deleterious 4-hydroxy-2alkenals. In a study performed by Awada et al. (2012), C57/BL6 mice fed on oxidised n-3 PUFA diet which was prepared by continuous shaking to reach the sufficient oxidation level, have been shown to demonstrate an increase in concentration of plasma 4-HHE in parallel with expression of GPx2, a gastrointestinal glutathione peroxidase and phosphorylation of NF- $\mathrm{kB}, \quad \mathrm{a}$ transcription factor involved in inflammation. Besides, higher concentrations of pro-inflammatory cytokine IL-6 and MCP-1 were observed in mice provided with oxidised n-3 PUFA diet. These results indicated that dietary consumption of $n-3$ PUFA leads to an accumulation of 4 -HHE in blood after their absorption by intestine, which subsequently induces oxidative stress and inflammation in the upper intestine.

A study done by Hamsi et al. (2015), SpragueDawley rats were fed on diet added with virgin coconut oils heated once, five times and 10 times at $180^{\circ} \mathrm{C}$, and each round of heating lasted for 15 min. There was an increase in the level of plasma inflammatory biomarkers, such as sICAM-1, sVCAM-1, high-sensitivity C-reactive protein (hsCRP) and $\mathrm{TXB}_{2}$ in the group with five times and 10 times heated oils. These results are further supported by Ng et al. (2012), which revealed that Sprague-Dawley rats fed on diet containing 15\% $(\mathrm{w} / \mathrm{w})$ of repeatedly heated palm oil at $180^{\circ} \mathrm{C}$ for $10 \mathrm{~min}$, had an increased expression of VCAM-1
Besides, in a study done by Sukalingam et al. (2016), the levels of catalase (CAT), superoxide dismutase (SOD) and glutathione, which are indicative of oxidative stress were increased in the blood collected from animals fed on diets containing palm oil heated for 5 to 10 times at $180^{\circ} \mathrm{C}$ for $15 \mathrm{~min}$. Oxidative stress is identified to cause inflammation; therefore, the consumption of repeatedly heated oil may induce inflammatory responses. Jaarin et al. (2015) also showed that the consumption of high fat diets added with repeatedly heated palm oil, which the temperature of each round reached $180^{\circ} \mathrm{C}$ and lasted for $10 \mathrm{~min}$, caused greater extent of inflammation in liver compared to control diet without any oil.

In a study conducted by Aruna et al. (2005), the activity of phospholipase A increased significantly in the liver of rats which consumed thermally oxidised oil when compared to the normal control rats. Phospholipase A catalyses the hydrolysis of phospholipids into lysophospholipid and free fatty acids (Gunawardena et al., 2014). Lysophospholipids generated can be converted into platelet-activating factor, a type of potent inflammatory mediator. On the other hand, the free fatty acids mainly generated is AA, which is also the precursor of eicosanoid family of potent inflammatory mediators, such as leukotrienes, lipoxins, prostaglandins and thromboxane (Bradshaw and Dennis, 2009). These results were further supported by Lin et al. (2000), which reported that $\mathrm{PGE}_{2}$ level in mice given diet containing $150 \mathrm{~g}$ of oxidised soyabean oil/ $\mathrm{kg}$ were significantly higher than the mice given diet containing $50 \mathrm{~g}$ of soyabean oil $/ \mathrm{kg}$. Also, higher level of $\mathrm{LTB}_{2}$ also produced in group given diet containing $150 \mathrm{~g}$ of oxidised soyabean oil $/ \mathrm{kg}$, compared to other groups that given diet containing $50 \mathrm{~g}$ of soyabean oil $/ \mathrm{kg}$, $50 \mathrm{~g}$ of oxidised soyabean oil $/ \mathrm{kg}$ and $150 \mathrm{~g}$ soyabean oil/kg respectively. Higher liver cytochrome P450 activity was also observed in mice given $50 \mathrm{~g}$ dietary oxidised oil $/ \mathrm{kg}$. AA can be oxidatively metabolised by cytochrome P450, consequently enhance the production of inflammatory mediators, such asepoxyeicosatrienoic acids (EET) and hydroxyeicosatetraenoic acids (HETE) (Gross et al., 2005).

\section{Epidemiological and Clinical Studies}

In a study done by Birlouez-Aragon et al. (2010), human subjects were assigned to two types of diet: standard diet (STD) and steamed diet (STMD), for four weeks to investigate the health risk of food heated under high temperature. Both experimental diets were designed to meet the French dietary demand, which contain equivalent quantities of energy and nutrients $35 \%$ of energy from carbohydrates, $15 \%$ of energy from proteins, and $32 \%$ of energy from fats). STD was cooked by using 
conventional methods, including frying, grilling and roasting, as well as comprising industrial food that are commonly being cooked extensively, such as coffee, dry cookies and extruded corn flakes. On the other hand, STMD contained food that were cooked with steam methods and involved minimal process, such as sponge cakes, tea and mildly baked bread. STD group which consumed mainly high temperature cooked foods were shown to have lesser concentrations of major antioxidant vitamins (vitamins $C$ and $E$ ), and total and reduced (uniquinol) coenzyme Q10 in the plasma compared to STMD group. The reduced concentration of plasma antioxidant vitamins indicated an enhanced oxidative stress and higher susceptibility of plasma lipids against oxidation after consumption of STD. Besides, STD group was demonstrated to have higher carboxymethyl-lysine (CML) content, which is known to be the indicator of Maillard reaction products (MRP). Increased dietary intake of MRP were known to promote the generation of pro-inflammatory cytokines and therefore play an important role in inflammation (Webster et al., 2005; Kitts et al., 2012). Hence, these findings suggested that the dietary intake of high-heattreated foods promotes inflammatory responses which are associated with higher risk of diseases, such as type-2 diabetes and cardiovascular diseases in healthy individuals. Even though this study did not specifically identify the effect of dietary fats after exposure to high temperature heating on the aforementioned outcomes, the findings however provide an insight into the detrimental impact of high temperature heating to the nutritional quality of cooked foods.

Besides, advanced glycation end-products (AGE) can be found readily in heat-treated foods. The consumption of dietary AGE, a pro-inflammatory mediator has been shown to increase the level of oxidative stress and inflammatory responses. These findings were supported by the study done by Uribarri et al. (2007), which revealed the positive correlation of the intake of dietary AGE and serum levels of hsCRP, an inflammatory marker. This study involved 172 healthy volunteers (70 men and 102 women), comprising 69\% Caucasian, 17\% Asian, 14\% African American. Serum samples obtained from the participants were used to test for two common protein-derived and lipid derived AGE: $\varepsilon \mathrm{N}-\mathrm{CML}$ and methylglyoxal (MG). The estimation of daily dietary consumption of AGE was done based on a three-day food records, including the information on cooking techniques. The study demonstrated that the serum level of AGE was positively correlated to the dietary consumption of AGE. Consequently, the increased amount of AGE has been reported to enhance oxidative stress and inflammatory responses, which was indicated by the increasing level of hsCRP. However, data derived from this study does not provide a direct measurement of the effect of oxidised oils on cellular inflammatory responses in human model, which may need further exploration.

\section{CANCER RISK OF OXIDISED LIPID}

Based on the molecular mechanisms and evidences from cellular, animal and human models, the oxidised lipids were revealed to have effects on the action of inflammatory cytokines, which were known to have inducing effects on tumour growth (Balkwill and Mantovani, 2001). Many studies have reported that the by-products generated during lipid oxidation will increase the risk of developing cancers, such as lung, breast, colon and liver cancers, which will be further discussed in this section.

\section{Lung Cancer}

The generation of products during lipid peroxidation can lead to release of substances which may cause changes in cell growth. Chang et al. (2005) demonstrated that 2,4-De, which can be found abundantly in heated oils, can lead to enhanced proliferation of human bronchial epithelial cells (BEAS-2B cells) and release of TNF- $\alpha$ and IL-1 $\beta$, which play an important role in tumour promotion. These results were supported by $\mathrm{Wu}$ and Yen (2004) who demonstrated that 2,4-De which formed during the heating of peanut oil can cause DNA damage in human lung carcinoma (A-549) cells.

Besides, trans,trans-2,4-decadienal ( $t$-DDE) is one of the most abundant and toxic aldehydes formed from the heating or oxidation of fatty acids, especially PUFA in cooking oils (Fullana et al., 2004). Wang et al. (2010) reported that there was a significant increase in the number of alveolar macrophages in bronchoalveolar lavage fluid (BALF) of mice exposed to $t t$-DDE. Nevertheless, there were also enhanced occurrence of bronchioloalveolar junctions (BAJ) hyperplasia and accumulation of phosphorylated signal transducer and activator of transcription 3 (pSTAT3), a type of pro-carcinogenic factor. These findings indicate that intake of oxidised oils containing $t t$-DDE might increase the risk of lung carcinogenesis.

\section{Breast Cancer}

In a case-control study performed by Wang et al. (1996), the level of lipid peroxidation-related DNA damage was significantly higher in normal breast tissues of cancer patients compared to noncancer controls. Therefore, lipid peroxidation may increase the risk of breast cancer as the products of lipid peroxidation can accumulate in human breast tissues. Welsch (1994) also stated that the products formed from the activity of cyclooxygenase on 
$\mathrm{AA}$, such as $\mathrm{PGE}_{2}$ might induce mammary gland tumorigenesis, subsequently increase the risk of breast cancer. Furthermore, Boyd and McGuire (1991) showed that high level of MDA was found in urine of women with mammographic dysplasia compared to normal women. Mammographic dysplasia is associated to higher risk of breast cancer, therefore, it is suggested that lipid peroxidation may increase the risk of getting breast cancer.

\section{Colon Cancer}

The primary auto-oxidation products of PUFA have been identified to induce DNA synthesis and ornithine decarboxylase activity in colonic mucosa. Bull et al. (1988) showed that autooxidation products of PUFA may increase the level of tumorigenesis due to their role in stimulating cell division. Besides, lipid peroxyl radicals produced during the oxidation of PUFA could increase the risk of colon cancer by causing DNA damage (Sawa et al., 1998).

In addition, a study had been conducted by Alghazeer et al. (2008) to compare the effects of two oxidised lipids: mackerel oil and methyl linoleate on the proliferation and viability of caco- 2 cells, which are human colon epithelial cancer cell line. There was significant decrease in cell viability, augmented thiobarbituric acid reactive substance (TBARS) level and induced apoptosis in cells treated with the both types of oxidised lipids. This result indicated that the oxidised lipids induce oxidation to the lipid membrane, followed by generation of harmful products which lead to damage or death of caco-2 cells.

Furthermore, in a study conducted by Udilovaa et al. (2003), lipid hydroperoxides present in heated oils were reported to induce lipid peroxidation of biomembranes and exert strong cytotoxic effects on cultured colon cells. On contrary, these effects were not seen when using untreated oils with low hydroperoxide content. Therefore, dietary consumption of oxidised oils may cause oxidative damage and cell death in colon, which lead to increased risk of colon cancer as a result of regenerative cell proliferation.

\section{Liver Cancer}

Based on the study done by Ichinose et al. (2004), the consumption of oxidised dietary oils may increase the risk of liver cancer. Benign hepatocellular adenoma was observed in the $\mathrm{C} 3 \mathrm{H} / \mathrm{HeN}$ male mice fed on three types of oxidised dietary oils: lard, soyabean oil and sardine oil. The mice group fed on oxidised sardine oil exhibited the greatest number of tumour incidence and malignant tumours. Besides, there was an increase in the level of 8-hydroxy-deoxyguanosine (8-OH-dG), a hydroxyl radical which was generated during lipid peroxidation, in the liver of mice fed on oxidised lard and oxidised sardine oils. These results indicate that the accumulation of $8-\mathrm{OH}-\mathrm{dG}$ is one of the factors that induce development and progression of liver tumour.

In addition to its adverse effects in causing inflammation, HNE acts as a second messenger of oxidative stress in physiological processes (Csala et al., 2015). HNE was known to interact readily with biomolecules such as nucleic acids and proteins due to its high reactivity. In a study conducted by Marquez-Quinones et al. (2010), HNE-protein adducts were observed in hepatocyte cytoplasm before the occurrence of hepatitis and their presence were apparent during hepatitis. The formation of HNE-protein adducts was found to be linked to the expression of gluthathione S-transferase P-form, which particularly associated with malignancy (Tew et al., 2011). These results indicate that the HNE protein-adduct formation might be implicated in the primary stages of hepatocyte cancer initiation.

\section{METHODOLOGICAL CONSIDERATIONS AND STUDY LIMITATIONS}

Many studies have been carried out to investigate the pro-inflammatory effects of oxidised oils. However, there are no consistent methods for oxidised oil preparation. The methods of preparation of oxidised oil are listed in Table 2. A variety of cooking utensils, such as saucepan, fry pan, wok and electrical fryer that are commonly used to fry or heat food have been used in previous studies (Yen et al., 2010; Fararh et al., 2012; Falade et al., 2015; Falade and Oboh, 2015; Jaarin and Kamisah, 2012; Leong et al., 2008; 2012; GomezAlonso et al., 2003; López-Varela et al., 1995; Owu et al., 1998; Farag et al., 2010). When the supply of oxygen is practically unlimited, the rate of oxidation increases when the oil sample has higher ratio of surface to volume (Crapiste et al., 1999). Therefore, the difference in size and shape of the cooking utensils will result in different levels of oxidation albeit other conditions remain constant.

Other than that, there is also a previous study using microwave oven and conventional oven to produce oxidised oil samples (Mahmoud et al., 2009). Microwave oven generates radiation while conventional oven uses a stagnant heat source to heat the oil samples. The effects of microwave heating on the oil samples can differ significantly from those heated using conventional oven and also conventional cooking methods (as mentioned earlier) due to the exposure of microwave energy. A high number of free radicals can be created from microwave energy which might further induce oxidation in lipids, especially PUFA that have 
TABLE 2. OXIDISED OIL PREPARATION METHODS

\begin{tabular}{|c|c|c|c|c|c|c|c|}
\hline No. & $\begin{array}{c}\text { Type of } \\
\text { vegetable oil }\end{array}$ & $\begin{array}{c}\text { Type of cooking } \\
\text { utensils }\end{array}$ & $\begin{array}{c}\text { Volume } \\
\text { (litre)/ } \\
\text { weight (kg) }\end{array}$ & $\begin{array}{c}\text { Temperature }\left({ }^{\circ} \mathrm{C}\right) \\
\text { Power }(\mathrm{W})\end{array}$ & Duration & $\begin{array}{l}\text { Type of food } \\
\text { fried using } \\
\text { heated oil and } \\
\text { duration }\end{array}$ & Reference \\
\hline 1 & Soyabean oil & $\begin{array}{c}\text { Iron saucepan } \\
\text { (bore of } \\
45 \mathrm{~cm} \text { and a depth } \\
\text { of } 20 \mathrm{~cm} \text { ) }\end{array}$ & 7 litres & $180 \pm 5^{\circ} \mathrm{C}$ & $\begin{array}{l}4 \text { intermittent } \\
\text { days, total } 22 \mathrm{hr}\end{array}$ & $\begin{array}{l}100 \mathrm{~g} \text { chicken } \\
\text { nuggets }(4 \mathrm{~min}) \\
\text { or sweet } \\
\text { potatoes }(2 \mathrm{~min})\end{array}$ & $\begin{array}{l}\text { Yen et al. } \\
(2010)\end{array}$ \\
\hline 2 & Sunflower oil & Cast iron wok & $3 \mathrm{~kg}$ & $200^{\circ} \mathrm{C}$ & $12 \mathrm{hr}$ and $24 \mathrm{hr}$ & $\begin{array}{l}\text { Wheat flour } \\
\text { dough sheets } \\
10 \times 4.5 \times 0.15 \mathrm{~cm}) \\
\text { for } 3 \mathrm{~min}\end{array}$ & $\begin{array}{l}\text { Fararh et al. } \\
\qquad(2012)\end{array}$ \\
\hline 3 & Palm oil & $\begin{array}{l}\text { Stainless steel } \\
\text { fry-pan }\end{array}$ & $\begin{array}{c}0.25 \text { litres } \\
\text { heated oil }+7.50 \\
\text { litres fresh oil }\end{array}$ & $180^{\circ} \mathrm{C}$ & 10,15 and $20 \mathrm{~min}$ & None & $\begin{array}{l}\text { Falade et al. } \\
\qquad(2015)\end{array}$ \\
\hline 4 & $\begin{array}{l}\text { Sunflower oil } \\
\text { (refined) }\end{array}$ & $\begin{array}{l}\text { Commercial } \\
\text { electrical fryer }\end{array}$ & $\begin{array}{c}3 \text { litres } \\
\text { (addition of } \\
4.5 \text { litres fresh } \\
\text { oil to replace the } \\
\text { oil loss during } \\
\text { frying) }\end{array}$ & e & $20 \mathrm{~min}$ & $\begin{array}{l}0.5 \mathrm{~kg} \text { potatoes } \\
(2 \mathrm{~mm} \text { thick }) \\
\text { for } 8 \mathrm{~min}\end{array}$ & $\begin{array}{c}\text { López-Varela et al. } \\
\text { (1995) }\end{array}$ \\
\hline 5 & Pure Arachis oil & $\begin{array}{l}\text { Stainless steel } \\
\text { frying pan }\end{array}$ & 0.25 litres & $220^{\circ} \mathrm{C}$ & $20 \mathrm{~min}$ & None & $\begin{array}{l}\text { Falade and } \\
\text { Oboh (2015) }\end{array}$ \\
\hline 6 & $\begin{array}{l}\text { Refined olive oil } \\
\text { and extra virgin } \\
\text { olive oil }\end{array}$ & $\begin{array}{c}\text { Pyrex Petri } \\
\text { dishes }(14 \mathrm{~cm} \\
\text { diameter }) \text { in } \\
\text { microwave oven } \\
\text { and conventional } \\
\text { oven }\end{array}$ & $0.025 \pm 0.001 \mathrm{~kg}$ & $\begin{array}{c}500 \mathrm{~W} \\
\text { (microwave } \\
\text { oven), } 200^{\circ} \mathrm{C} \\
\text { (conventional } \\
\text { oven) }\end{array}$ & $\begin{array}{c}3,6,9,12,15,20 \\
25 \text { and } 30 \mathrm{~min}\end{array}$ & None & $\begin{array}{l}\text { Mahmoud et al. } \\
\text { (2009) }\end{array}$ \\
\hline 7 & $\begin{array}{c}\text { Palm oil or } \\
\text { soya oil }\end{array}$ & Stainless steel wok & 2.5 litres & $180^{\circ} \mathrm{C}$ & $\begin{array}{l}10 \text { min ( } 5 \text { times } \\
\text { heating with } \\
\text { cooling interval } \\
\text { of } \geq 5 \text { hr) }\end{array}$ & $\begin{array}{r}\text { Sweet potato } \\
\text { slices }(1 \mathrm{~kg})\end{array}$ & $\begin{array}{c}\text { Jaarin and } \\
\text { Kamisah (2012) }\end{array}$ \\
\hline 8 & $\begin{array}{c}\text { Refined } \\
\text { sunflower, palm } \\
\text { and canola oil }\end{array}$ & Deep fat-dryer & 2 litres & $180 \pm 5^{\circ} \mathrm{C}$ & $\begin{array}{c}5 \mathrm{hr} \text { (4 times) } \\
\text { per day for } 4 \text { days }\end{array}$ & $\begin{array}{l}\text { Potato chips } \\
(2,4,50 \mathrm{~mm})\end{array}$ & $\begin{array}{l}\text { Farag et al. } \\
\qquad(2010)\end{array}$ \\
\hline 9 & Palm oil & Stainless steel wok & 2.5 litres & $180^{\circ} \mathrm{C}$ & $\begin{array}{l}10 \text { min heating with } \\
\text { (5 or } 10 \text { times } \\
\text { cooling interval } \\
\text { of } 5 \text { hr) }\end{array}$ & $\begin{array}{l}\text { Sweet potato } \\
\text { slices }(1 \mathrm{~kg})\end{array}$ & $\begin{array}{l}\text { Leong et al. } \\
(2008 ; 2012)\end{array}$ \\
\hline 10 & $\begin{array}{l}\text { Extra virgin } \\
\text { olive oil and } \\
\text { refined olive oil }\end{array}$ & Deep fryer & 2 litres & $180^{\circ} \mathrm{C}$ & $\begin{array}{c}10 \mathrm{~min} \\
\text { (2 operations } \\
\text { per day for } 6 \text { days })\end{array}$ & $\begin{array}{c}\text { Potato slices } \\
(200 \mathrm{~g})(40-50 \times \\
10 \times 10 \mathrm{~mm})\end{array}$ & $\begin{array}{l}\text { Gomez- } \\
\text { Alonso et al. } \\
\quad \text { (2003) }\end{array}$ \\
\hline 11 & Palm oil & Stainless steel pot & $\begin{array}{c}\text { Not } \\
\text { mentioned }\end{array}$ & $150^{\circ} \mathrm{C}$ & $20 \min$ (5 rounds) & None & $\begin{array}{c}\text { Owu et al. } \\
\text { (1998) }\end{array}$ \\
\hline
\end{tabular}

weaker double bond which readily accept oxygen to form free radical (Ajayi et al., 2014).

The volume of oil samples used in the heating process also varies from 0.25 litres to 7 litres. According to Choe and Min (2006), oxygen and oil samples can react efficiently when the size of oil sample is small or high ratio of surface to volume. Therefore, the difference in the volume of oil samples will result in different degrees of oxidation, consequently producing different amount of oxidation by-products. Based on previous studies listed in Table 2, most of the studies heated the oil samples at around $180^{\circ} \mathrm{C}$ which is the temperature commonly used in frying purposes. In addition, there are also some studies using heated oils to fry food to mimic frying conditions. However, 
inconsistent choices of food used in the studies, such as nuggets, sweet potatoes and wheat flour dough might bring about the formation of different levels of oxidation products due to the chemical reactions between the food products and oil samples. Therefore, a standardised and consistent method in preparing oxidised oil samples is needed in generating comparable results with regards to this topic.

Besides, the storage methods of oxidised oils have not been unified. It has been reported that the level of oxidation is affected by the temperature, light, and the presence of oxygen and moisture (Choe and Min, 2007). Therefore, due to the inconsistent methods used, the data obtained from previous research can be hardly compared. The laboratory output of lipid oxidation products is also further complicated by the possible interactions of oxidised oils with the other components in the samples and chemicals used during analysis, and their tendency to undergo further reactions (Dabrowska et al., 2015). Therefore, it is always recommended to use at least three different analytical methods to obtain more accurate results.

Furthermore, the study of oxidised oils is hardly to be conducted up to clinical level due to ethical considerations. Therefore, the inflammation-related cancer risk due to consumption of oxidised oil among human can only be studied by correlating their eating habit and health status. However, food survey is not always accurate and reliable. Most of the oxidised oils studies have been conducted using cellular and animal models. However, there are significant differences between the growth of cells in in vivo and in vitro conditions, for instance, the tumour-promoting effect of oxidised lipids might be significant in in vitro condition, but less significant in the human body due to the complexity of human system. Rodent models are the common choice to mimic human biological system. However, the differences in size, tissue development, lifespan and biological system between rodent and human models are still the factors that impede the progress of research in this area.

\section{CONCLUSION}

Based on the evidence available, the dietary intake of oxidised oils may enhance the generation of inflammatory molecules, which have been reported to have promoting effects on tumour growth. Hence, the consumption of repeatedly heated oils, which have enhanced level of oxidation, will increase the risk of cancers. However, there is still lack of evidence on the risk of inflammatory-induced cancers due to the consumption of oxidised oils, therefore more studies are warranted to reveal the link between oxidised oils and cancer progression.

\section{ACKNOWLEDGEMENT}

The authors wish to express their gratitude to the Director-General of MPOB for permission to publish this article. This work is supported by research grant from MPOB.

\section{REFERENCES}

Abdelmonem, MA and Khogali, EN A I (2012). Effect of storage packaging on sunflower oil oxidative stability. American J. Food Technology, 7: 700-707.

Ahmad Tarmizi, A H and Ismail, R (2007). Comparison of the frying stability of standard palm olein and special quality palm olein. J. Amer. Oil Chem. Soc., 85: 245-251.

Ajayi, F A; Afolabi, R O; Chukwudozie, C N and Osuntoki, A A (2014). Consumption of microwaved food induces oxidative stress in the liver and brain of Sprague-Dawley rats. J. Environmental Science, Toxicology and Food Technology, 8: 21-24.

Alghazeer, R; Gao, H and Howell, N K (2008). Cytotoxicity of oxidised lipids in cultured colonal human intestinal cancer cells (caco-2 cells). Toxicology Letters, 180: 202-11.

Ali, AMand Abdurrhman, AM (2013). Determination of free fatty acids in palm oil samples by nonaqueous flow injection using salicyaldehyde-2, 4-dinitrophenylhydrazone as colorimetric reagent. Chemical and Materials Engineering, 1: 96-103.

Anwar, F; Shahid Chatha, S A and Ijaz Hussain, A (2007). Assessment of oxidative deterioration of soybean oil at ambient and sunlight storage. Grasas $y$ aceites, 58: 390-395.

Aruna, K; Rukkumani, R; Varma, P S and MENON, V P (2005). Therapeutic role of Cuminum cyminum on ethanol and thermally oxidized sunflower oil induced toxicity. Pharmacological and Toxicological Evaluation of Natural Product Derivatives, 19: 416-421.

Atinafu, D G and Bedemo, B (2011). Estimation of total free fatty acid and cholesterol content in some commercial edible oils in Ethiopia, Bahir DAR. J. Cereals and Oilseeds, 2: 71-76.

Awada, M; Soulage, C O; Meynier, A; Debard, C; Plaisancie, P; Benoit, B; Picard, G; Loizon, E; Chauvin, MA; Estienne, M; Peretti, N; Guichardant, M; Lagarde, M; Genot, C and Michalski, M C (2012). Dietary oxidized n-3 PUFA induce oxidative stress and inflammation: Role of intestinal absorption of 4-HHE and reactivity in intestinal cells. J. Lipid Research, 53: 2069-80. 
Ayala, A; Munoz, M F and Arguelles, S (2014). Lipid peroxidation: production, metabolism, and signaling mechanisms of malondialdehyde and 4-hydroxy-2-nonenal. Oxidative Medicine and Cellular Longevity, 2014: 360438.

Balkwill, F and Mantovani, A (2001). Inflammation and cancer: Back to Virchow? The Lancet, 357: 539545.

Barriuso, B; Astiasarán, I and Ansorena, D (2013). A review of analytical methods measuring lipid oxidation status in foods: A challenging task. European Food Research and Technology, 236: 1-15.

Birlouez-Aragon, I; Saavedra, G; Tessier, F J; Galinier, A; Ait-Ameur, L; Lacoste, F; Niamba, C N; Alt, N; Somoza, V and Lecerf, J M (2010). A diet based on high-heat-treated foods promotes risk factors for diabetes mellitus and cardiovascular diseases. The American J. Clinical Nutrition, 91: 12201226 .

Boyd, N and Mcguire, V (1991). The possible role of lipid peroxidation in breast cancer risk. Free Radical Biology and Medicine, 10: 185-190.

Bradshaw, R A and Dennis, E A (2009). Handbook of Cell Signaling. Academic press.

Bremner, D; Magill, W; Deighton, N and Benson, E (1997). An evaluation of analytical methods for the detection of secondary oxidation products in dedifferentiated plant cultures. Phyton-Horn, 37: 39-44.

Bull, A W; Nigro, N D and Marnett, L J (1988). Structural requirements for stimulation of colonic cell proliferation by oxidized fatty acids. Cancer Research, 48: 1771-1776.

Calder, P C (2009). Polyunsaturated fatty acids and inflammatory processes: New twists in an old tale. Biochimie, 91: 791-795.

Chang, L W; Lo, W S and Lin, P (2005). Trans, trans-2,4-decadienal, a product found in cooking oil fumes, induces cell proliferation and cytokine production due to reactive oxygen species in human bronchial epithelial cells. Toxicological Sciences, 87: 337-343.

Chaudhary, A; Mishra, A and Sethi, S (2004). Oxidized $\omega-3$ fatty acids inhibit pro-inflammatory responses in glomerular endothelial cells. Nephron Experimental Nephrology, 97: e136-e145.

Choe, E and Min, DB (2006). Mechanisms and factors for edible oil oxidation. Comprehensive Reviews in Food Science and Food Safety, 5: 169-186.
Choe, E and Min, D B (2007). Chemistry of deep-fat frying oils. J. Food Science, 72: R77-R86.

Crapiste, G H; Brevedan, M I and Carelli, A A (1999). Oxidation of sunflower oil during storage. J. Amer. Oil Chem. Soc., 76: 1437.

Csala, M; Kardon, T; Legeza, B; Lizak, B; Mandl, J; Margittai, E; Puskas, F; Szaraz, P; Szelenyi, P and Banhegyi, G (2015). On the role of 4-hydroxynonenal in health and disease. Biochimica et Biophysica Acta (BBA)-Molecular Basis of Disease, 1852: 826-838.

Dabrowska, M; Zielinska, A and Nowak, I (2015). Lipid oxidation products as a potential health and analytical problem. Chemik, 69: 92-94.

Delany, J P; Windhauser, M M; Champagne, C M and Bray, G A (2000). Differential oxidation of individual dietary fatty acids in humans. The American J. Clinical Nutrition, 72: 905-911.

Eder, K (1999). The effects of a dietary oxidized oil on lipid metabolism in rats. Lipids, 34: 717-725.

Eder, K; Keller, U; Hirche, F and Brandsch, C (2003). Thermally oxidized dietary fats increase the susceptibility of rat LDL to lipid peroxidation but not their uptake by macrophages. The J. Nutrition, 133: 2830-2837.

Esterbauer, H and Cheeseman, K H (1990). [42] Determination of aldehydic lipid peroxidation products: Malonaldehyde and 4-hydroxynonenal. Methods in Enzymology, 186: 407-421.

Falade, A O and Oboh, G (2015). Thermal oxidation induces lipid peroxidation and changes in the physicochemical properties and beta -carotene content of arachis oil. International J. Food Science, 2015: 806524

Falade, A O; Oboh, G; Ademiluyi, A O and Odubanjo, O V (2015). Consumption of thermally oxidized palm oil diets alters biochemical indices in rats. Beni-Suef University J. Basic and Applied Sciences, 4: 150-156.

Farag, R S; Abdel-Latif, M S; Basuny, A M M and Hakeem, B S A E (2010). Effect of non-fried and fried oils of varied fatty acid composition on rat organs. Agric. Biol. Jn. Am. 1: 501-509.

Fararh, K; Abdel-Fattah, F A and Ahmed, T E (2012). Dietary oxidized frying oil induces hyperglycemia and decreases activities of energy metabolism related enzymes in Mice. J. Animal Science Advance, 2: 847-856. 
Frankel, E (1984). Lipid oxidation: mechanisms, products and biological significance. J. Amer. Oil Chem. Soc., 61: 1908-1917.

Fregaa, N; Mozzona, M and Lerckerb, G (1999). Effects of free fatty acids on oxidative stability. $J$. Amer. Oil Chem. Soc., 76: 325-329.

Freire, P C M; Lobo, L C B; Freitas, G, S. and Ferreira, T A P C (2013). Quality of deep frying oils and fats used in street-fairs in Goiânia, Brazil. Food Science and Technology, 33: 569-576.

Fullana, A; Carbonell-Barrachina, A and Sidhu, S (2004). Comparison of volatile aldehydes present in the cooking fumes of extra virgin olive, olive, and canola oils. J. Agricultural and Food Chemistry, 52: 5207-5214.

Gaweł, S; Wardas, M; Niedworok, E and Wardas, $P$ (2003). Malondialdehyde (MDA) as a lipid peroxidation marker. Wiadomosci Lekarskie (Warsaw, Poland: 1960), 57: 453-455.

Gomez-Alonso, S; Fregapane, G; Salvador, M D and Gordon, M H (2003). Changes in phenolic composition and antioxidant activity of virgin olive oil during frying. J. Agricultural and Food Chemistry, 51: 667-672.

Gross, G J; Falck, J R; Gross, E R; Isbell, M; Moore, J and Nithipatikom, K (2005). Cytochrome P450 and arachidonic acid metabolites: Role in myocardial ischemia/reperfusion injury revisited. Cardiovasc. Res. 68: 18-25.

Gunawardena, D; Govindaraghavan, S and Münch, G (2014). Anti-inflammatory properties of cinnamon polyphenols and their monomeric precursors. Polyphenols in Human Health and Disease, 1: 409-425.

HamsI, M A; Othman, F; Das, S; Kamisah, Y; Thent, Z C; Qodriyah, H M S; Zakaria, Z; Emran, A; Subermaniam, K and Jaarin, K (2015). Effect of consumption of fresh and heated virgin coconut oil on the blood pressure and inflammatory biomarkers: An experimental study in Sprague Dawley rats. Alexandria J. Medicine, 51: 53-63.

Ichinose, T; Nobuyuki, S; Takano, H; Abe, M; Sadakane, K; Yanagisawa, R; Ochi, H; Fujioka, K; Lee, K G and Shibamoto, T (2004). Liver carcinogenesis and formation of 8-hydroxydeoxyguanosine in $\mathrm{C} 3 \mathrm{H} / \mathrm{HeN}$ mice by oxidized dietary oils containing carcinogenic dicarbonyl compounds. Food Chem. Toxicol., 42: 1795-803.
Jaarin, K and Kamisah, Y (2012). Chapter 10: Repeatedly heated vegetable oils and lipid peroxidation. INTECH: 211-228.

Jaarin, K; Nor-Aini, U; Siti-Aishah, M and Das, S (2015). Palm oil fat diet consumption and its effects on serum liver enzymes and microscopic changes in experimental rats. Pakistan J. Nutrition, 14: 575.

Kaleem, A; Aziz, S; Iqtedar, M; Abdullah, R; Aftab, F R; Shakoori, F R and Naz, S (2015). Investigating changes and effect of peroxide values in cooking oils subject to light and heat. FUUAST J. Biology, 5: 191196.

Kanner, J (2007). Dietary advanced lipid oxidation endproducts are risk factors to human health. Molecular Nutrition E Food Research, 51: 1094-1101.

Kitts, D D; Chen, X-M and Jing, H (2012). Demonstration of antioxidant and antiinflammatory bioactivities from sugar-amino acid Maillard reaction products. J. Agricultural and Food Chemistry, 60: 6718-6727.

Kris-Etherton, P M and Committee, N (1999). Monounsaturated fatty acids and risk of cardiovascular disease. Circulation, 100: 1253-1258.

Kummerow, F A; Zhou, Q; Mahfouz, M M; Smiricky, M R; Grieshop, C M and Schaeffer, D J (2004). Trans fatty acids in hydrogenated fat inhibited the synthesis of the polyunsaturated fatty acids in the phospholipid of arterial cells. Life Sciences, 74: 27072723.

Leong, X F; Aishah, A; Aini, U N; Das, S and JAARIN, K (2008). Heated palm oil causes rise in blood pressure and cardiac changes in heart muscle in experimental rats. Archives of Medical Research, 39: 567-572.

Leong, X F; Ng, C Y; Jaarin, K and Mustafa, M R (2015). Effects of repeated heating of cooking oils on antioxidant content and endothelial function. Austin J. Pharmacology and Therapeutics, 3(2): 1068.

Leong, X F; Salimon, J; Mustafa, M R and Jaarin, K (2012). Effect of repeatedly heated palm olein on blood pressure-regulating enzymes activity and lipid peroxidation in rats. The Malaysian J. Medical Sciences, 19: 20.

Leyton, J; Drury, P and Crawford, M (1987). Differential oxidation of saturated and unsaturated fatty acids in vivo in the rat. British J. Nutrition, 57: 383-393.

Lin, B F; Lai, C C; Lin, K W and Chiang, B L (2000). Dietary oxidized oil influences the levels of type 2 
T-helper cell-related antibody and inflammatory mediators in mice. British J. Nutrition, 84: 911-917.

Lise Halvorsen, B and Blomhoff, R (2011). Determination of lipid oxidation products in vegetable oils and marine omega-3 supplements. Food \& Nutrition Research, 55: 5792.

López-Varela, S; Sánchez-Muniz, F and Cuesta, C (1995). Decreased food efficiency ratio, growth retardation and changes in liver fatty acid composition in rats consuming thermally oxidized and polymerized sunflower oil used for frying. Food and Chemical Toxicology, 33: 181-189.

Maehre, H K; Jensen, I J; Elvevoll, E O and Eilertsen, K E (2015). Omega-3 fatty acids and cardiovascular diseases: Effects, mechanisms and dietary relevance. International J. Molecular Sciences, 16: 22636-22661.

Mahesar, S; Sherazi, S; Khaskheli, A R and Kandhro, AA (2014). Analytical approaches for the assessment of free fatty acids in oils and fats. Analytical Methods, 6: 4956-4963.

Mahmoud, E A E M; Dostálová, J; Pokorny̆, J; Lukešová, D and Doležal, M (2009). Oxidation of olive oils during microwave and conventional heating for fast food preparation. Czech J. Food Sciences, 27: S173-S177.

Mannekote, J K and Kailas, S V (2012). The effect of oxidation on the tribological performance of few vegetable oils. J. Materials Research and Technology, 1: 91-95.

Marquez-Quinones, A; Cipak, A; Zarkovic, K; Fattel-Fazenda, S; Villa-Trevino, S; Waeg, G; Zarkovic, N and Gueraud, F (2010). HNE-protein adducts formation in different pre-carcinogenic stages of hepatitis in LEC rats. Free Radic Res, 44: 119-27.

Miyashita, K and Takagi, T (1986). Study on the oxidative rate and prooxidant activity of free fatty acids. J. Amer. Oil Chem. Soc., 63: 1380-1384.

Mohdaly, A A A; Sarhan, M A; Mahmoud, A; Ramadan, M F and Smetanska, I (2010). Antioxidant efficacy of potato peels and sugar beet pulp extracts in vegetable oils protection. Food Chemistry, 123: 1019-1026.

Nayak, P K; Dash, U; Rayaguru, K and Krishnan, K $R$ (2016). Physico-chemical changes during repeated frying of cooked oil: A review. J. Food Biochemistry, 40:371-390.

Naz, S; Sheikh, H; Siddiqi, R and Sayeed, S A (2004). Oxidative stability of olive, corn and soybean oil under different conditions. Food Chemistry, 88: 253259.

Ng, C Y; Kamisah, Y; Faizah, O; Jubri, Z; Qodriyah, H M and Jaarin, K (2012). Involvement of inflammation and adverse vascular remodelling in the blood pressure raising effect of repeatedly heated palm oil in rats. Int. J. Vasc. Med., 2012: 404025.

Obembe, A O; Ofutet, E O; Antai, A B and Osim, E E (2016). Gastric ulceration: The role of thermoxidized palm oil. Nutrition E Food Science, 46: 108-119.

Owu, D U; Osim, E E and Ebong, P E (1998). Serum liver enzymes profile of Wistar rats following chronic consumption of fresh or oxidized palm oil diets. Acta Tropica, 69: 65-73.

Patterson, E; Wall, R; Fitzgerald, G F; Ross, R P and Stanton, C (2012). Health implications of high dietary omega-6 polyunsaturated fatty acids. J. Nutr. Metab., 2012: 539426.

Penumetcha, M; Khan, $\mathrm{N}$ and Parthasarathy, S (2000). Dietary oxidized fatty acids: An atherogenic risk? J. Lipid Research, 41: 1473-1480.

Pizzimenti, S; Ciamporcero, E; Daga, M; Pettazzoni, P; Arcaro, A; Cetrangolo, G; Minelli, R; Dianzani, C; Lepore, A; Gentile, F and Barrera, $G$ (2013). Interaction of aldehydes derived from lipid peroxidation and membrane proteins. Front. Physiol., 4: 242.

Poiana, M A (2012). Enhancing oxidative stability of sunflower oil during convective and microwave heating using grape seed extract. Int. J. Mol. Sci., 13: 9240-59.

Sadoudi, R; Ammouche, A and Ali Ahmed, D (2013). Effect of ingestion of thermally oxidized sunflower oil on the fatty acid composition and histological alteration of rat liver and adipose tissue in development. African J. Agricultural Research, 8: 3107-3112.

Sawa, T; Akaike, T; Kida, K; Fukushima, Y; Takagi, K and Maeda, H (1998). Lipid peroxyl radicals from oxidized oils and heme-iron: Implication of a highfat diet in colon carcinogenesis. Cancer Epidemiology Biomarkers \& Prevention, 7: 1007-1012.

Sethi, S; Eastman, A Y and Eaton, J W (1996). Inhibition of phagocyte-endothelium interactions by oxidized fatty acids: A natural anti-inflammatory mechanism? J. Laboratory and Clinical Medicine, 128: 27-38.

Sethi, S; Ziouzenkova, O; Ni, H; Wagner, D D; Plutzky, J and Mayadas, T N (2002). Oxidized 
omega-3 fatty acids in fish oil inhibit leukocyteendothelial interactions through activation of PPAR alpha. Blood, 100: 1340-1346.

Silaste, M-L; Rantala, M; Alfthan, G; Aro, A; Witztum, J L; Kesäniemi, Y A and Hörkkö, S (2004). Changes in dietary fat intake alter plasma levels of oxidized low-density lipoprotein and lipoprotein (a). Arteriosclerosis, Thrombosis and Vascular Biology, 24: 498-503.

Straliotto, M R; Hort, M A; Fiuza, B; Rocha, J B; Farina, M; Chiabrando, G and De Bem, A F (2013). Diphenyl diselenide modulates oxLDL-induced cytotoxicity in macrophage by improving the redox signaling. Biochimie., 95: 1544-1551.

Sukalingam, K; Jaarin, K; Saad, Qh m; Mohamed, S and Othman, F (2016). Consumption of ADD-X and repeatedly heated palm oil on the blood pressure and oxidative stress markers in ovarectmized rats. International J. Pharmacology, 12: 514-522.

Tew, K D; Manevich, Y; Grek, C; Xiong, Y; Uys, J and Townsend, D M (2011). The role of glutathione S-transferase $\mathrm{P}$ in signaling pathways and S-glutathionylation in cancer. Free Radic. Biol.Med., 51: 299-313.

Udilovaa, N; Jurekb, D; Marianb, B; Gillea, L; Schulte-Hermannb, R and Nohl, H (2003). Induction of lipid peroxidation in biomembranes by dietary oil components. Food and Chemical Toxicology, 41: 1481-1489.

Uribarri, J; Cai, W; Peppa, M; Goodman, S; Ferrucci, L; Striker, G and Vlassara, H (2007). Circulating glycotoxins and dietary advanced glycation endproducts: Two links to inflammatory response, oxidative stress, and aging. The J. Gerontology Series A: Biological Sciences and Medical Sciences, 62: 427-433.

Wang, C K; Chang, L W; Chang, H; Yang, C H; Tsai, M H; Tsai, H T and Lin, P (2010). Pulmonary changes induced by trans,trans-2,4-decadienal, a component of cooking oil fumes. Eur. Respir. J., 35: 667-675.
Wang, M; Dhingra, K; Hittelman, W N; Liehr, J G; De Andrade, M and LI, D (1996). Lipid peroxidationinduced putative malondialdehyde-DNA adducts in human breast tissues. Cancer Epidemiology Biomarkers $\mathcal{E}$ Prevention, 5: 705-710.

Waraho, T; Mcclements, D J and Decker, E A (2011). Impact of free fatty acid concentration and structure on lipid oxidation in oil-in-water emulsions. Food Chemistry, 129: 854-859.

Webster, J; Wilke, M; Stahl, P; Kientsch-Engel, R and Münch, G (2005). Maillard reaction products in food as pro-inflammatory and pro-arteriosclerotic factors of degenerative diseases. Zeitschrift fur Gerontologie und Geriatrie, 38: 347-353.

Welsch, C W (1994). Review on the effects of dietary fat on experimental mammary gland tumorigenesis: Role of lipid peroxidation. Free Radical Biology and Medicine, 18: 757-773.

Wu, S C and Yen, G C (2004). Effects of cooking oil fumes on the genotoxicity and oxidative stress in human lung carcinoma (A-549) cells. Toxicology in vitro, 18: 571-580.

Yen, P L; Chen, B H; Yang, F L and Lu, Y F (2010). Effects of deep-frying oil on blood pressure and oxidative stress in spontaneously hypertensive and normotensive rats. Nutrition, 26: 331-336.

Yildiz, G; Wehling, R L and Cuppett, S L (2001). Method for determining oxidation of vegetable oils by near-infrared spectroscopy. J. Amer. Oil Chem. Soc., 78: 495-502.

Yun, J M and Surh, J (2012). Fatty acid composition as a predictor for the oxidation stability of Korean vegetable oils with or without induced oxidative stress. Prev. Nutr. Food Sci., 17: 158-165.

Zahir, E; Rehana, S; Mehwish, H A and Anjum, Y (2017). Study of physicochemical properties of edible oil and evaluation of frying oil quality by Fourier transform-infrared (FT-IR) spectroscopy. Arabian J. Chem., 10: S3870-S3876. 